\title{
REVERSE OSMOSIS IN DECRYSTALLIZED NYLON 6 AND DECRYSTALLIZED ACRYLIC ACID GRAFTED NYLON 6 MEMBRANES
}

\author{
By Shoji Takigami, Fumihiko Kobayashi and Yoshio Nakamura
}

(Faculty of Technology, Gunma University, Kiryu, Gunma 376, Japan)

\section{Synopsis}

Nylon 6 film and acrylic acid grafted nylon 6 membranes prepared by $r$-irradiation method were reacted with paraformaldehyde and lactic acid in the presence of acid catalysts. Decrystallized nylon 6 (DN) and decrystallized grafted nylon 6 (DGN) membranes were thus obtained. The reverse osmosis properties of the membranes were investigated. The hydraulic permeability coefficient, $K_{1}$, of water increased with increasing the volume fraction of water in the swollen membranes. Although the salt rejection, $R_{\mathrm{s}}$, decreased with increasing the volume fraction for DN and $50 \%$ grafted DGN membranes, this pattern was not observed for the DGN membranes with more than $100 \%$ grafting. For the latter membranes the salt rejection decreased only slightly even at higher $K_{1}$ values. An equation to relate $R_{\mathrm{s}}$ to $K_{1}$ is described. For the parallel transport of pure water and salt solution with the same concentration of the feed solution through different parts of the swollen membranes, the salt rejection, $R_{\mathrm{s}}$, can be represented as

$$
1 / R_{\mathrm{s}}=\left(k V_{0} / V_{1}\right)\left(B /\left(B-\ln K_{1}+\ln K_{0}\right)\right)+(1-k)
$$

where $k$ is the rate ratio of the volume flows in pure water and in the salt solution. $V_{1} / V_{0}$ represents the fraction of the volume of the pure water phase in the total membrane volume. $B$ and $K_{0}$ are constants.

\section{Introduction}

It has been reported that the permeability of solutes through nylon 6 films is improved by graft copolymerization of acrylamide (AM) and acrylic acid (AA) onto the films." ) It has also been noted that the diffusion coefficient of $\mathrm{KCl}$ through $\mathrm{AA}$ grafted membranes shows a remarkable dependence on the salt concentration of the solution. ${ }^{2)}$

Recently, many kinds of ionic membranes prepared by graft copolymerization have been investigated for reverse osmosis experiments. ${ }^{3), 4)}$ Yasuda et $\mathrm{a}^{\mathbf{3})}$ studied the relationship between the salt rejection and the hydraulic permeability coefficient of water in ionic membranes, and proposed that pure water and the salt solution (having the same concentration as the feed solution) are transported through different parts of the swollen membrane. In this paper, decrystallized nylon 6 and decrystallized AA-grafted nylon 6 membranes
(N-(1-carboxy)ethoxymethylated derivatives) have been prepared by $\mathrm{N}$-substitution reaction to the amide groups on nylon 6 , and the reverse osmosis properties of such membranes are described and discussed in terms of a modified Yasuda's model.

\section{Experimental}

A biaxially stretched nylon 6 film $\left(1.5 \times 10^{-3}\right.$ $\mathrm{cm}$ in thickness) was used as a starting material. This film was irradiated with ${ }^{60} \mathrm{Co} r$-rays at an exposure rate of $1 \times 10^{6} \mathrm{R} / \mathrm{h}$ for $1 \mathrm{~h}$ at room temperature and under nitrogen atmosphere. Graft copolymerization of acrylic acid (AA) onto the irradiated film was carried out in a reaction system of AA-water (20:80 wt \%) under nitrogen atmosphere at $30^{\circ} \mathrm{C}$. Nylon 6 film and AA grafted nylon 6 membrane were reacted with paraformaldehyde $(10 \mathrm{~g})$ and lactic acid $(9 \mathrm{~g})$ in the presence of acid catalysts (formic acid $(30-40 \mathrm{wt} \%$ ) and phosphoric acid $(9-15 \mathrm{wt} \%))$ at $60^{\circ} \mathrm{C}$ to produce 
decrystallized nylon 6 (DN) and decrystallized grafted nylon 6 (DGN) membranes, both of which consisted of $\mathrm{N}$-(1-carboxy)ethoxymethylated derivatives and cross-linked polymers with methylene linkages. The weighed samples were immersed in $0.1 \mathrm{~mol} / 1$ potassium chloride aqueous solution, and after equilibrium, they were weighed as the same manner described in our previous paper. ${ }^{1)}$ Subsequently, the weight of the swollen membrane was converted into the volume of the swollen membrane. The volume fraction of water in the swollen membrane, $H$, was calculated from the following equation:

$$
H=\frac{\text { Volume of water in swollen membrane }}{\text { Volume of swollen membrane }}
$$

Reverse osmosis measurements were carried out with $0.1 \mathrm{~mol} / 1$ potassium chloride solution at an applied pressure of $100 \mathrm{~kg} / \mathrm{cm}^{2}$ at $25 \pm 0.5^{\circ} \mathrm{C}$ by using a reverse osmosis apparatus (Tama Seiki Kogyo Co.) with an effective membrane area of $17.3 \mathrm{~cm}^{2}$. The feed solution was stirred magnetically at $1000 \mathrm{rpm}$ during the measurements.

The hydraulic permeability coefficient, $K_{1}$, of water and salt rejection, $R_{s}$, were calculated according to the following equations:

$$
\begin{aligned}
& J_{1}=K_{1}(\Delta p-\Delta \pi) / \Delta X \\
& R_{\mathrm{s}}=1-\left(C^{\prime \prime} / C^{\prime}\right)
\end{aligned}
$$

where $J_{1}$ is the water flux per unit area of membrane, $\Delta p$ is the pressure difference across the membrane, $\Delta \pi$ is the osmotic pressure, $\Delta X$ is the thickness of the membrane, $C^{*}$ is the molar concentration of the salt in the feed solution and $C^{\prime \prime}$ is the concentration of the salt in the effluent.

\section{Results and Discussion}

The volume fraction of water, $H$, in swollen nylon 6 membranes changed from $6.2 \%$ to $36.6 \%$ by the $\mathrm{N}$-substitution reaction (formic acid $40 \%$ and phosphoric acid 15\%). Since the value of $H$ is a quantity reflecting the fine structure of polymer, it is considered that the degree of crystallinity of nylon 6 film is decreased by the reaction. The relationships between the effluent volume and measurement time for decrystallized nylon 6 (DN) and decrystallized grafted nylon 6 (DGN) membranes are shown in Fig. 1. The volume of the effluent increased linearly with the time after $2 \mathrm{~h}$

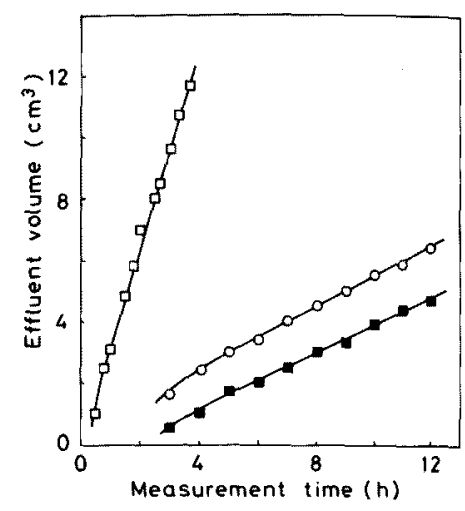

Fig. 1. Effluent volume vs. measurement time.

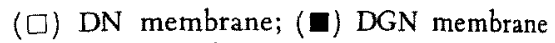
with $57 \%$ grafting; (O) DGN membrane with $150 \%$ grafting.

for DN and after 4 h for the DGN membranes, The DN membrane showed a higher effluent value than the DGN membranes, which is partly attributable to the difference in membrane thicknesses. The volume flux, $J_{\mathrm{v}}$, was determined from the slope of the linear part of the relationship and the membrane areas. Since this calculated $J_{v}$ was almost the same value as $J_{1}$, the hydraulic permeability coefficient of water, $K_{1}$, was calculated according to eq. (2). It was found that $K_{1}$ increased with the volume fraction, $H$, for DN and DGN membranes. Yasuda et $\mathrm{a}^{5)}$ have been reported that $K_{1}$ for highly hydrated membranes can be expressed by the following empirical equation regardless of the varieties of polymer membranes:

$$
K_{1}=K_{0} \exp (-B(1-H) / H)
$$

where $K_{0}$ and $B$ are constants. The relationships between $\log K_{1}$ and $1 / H-1$ for DN and DGN membranes are shown in Fig. 2. $\log K_{1}$ for DN membranes decreased linearly with increasing the value of $1 / H-1$ in the range $1 / H-1<4$, but for $1 / H-1>4$ the decrease in $K_{1}$ became less pronounced. Although a similar relationship was found for DGN membranes, DGN membranes with about $50 \%$ grafting showed a pattern different from that obtained for DGN membranes with more than $100 \%$ grafting. This difference may be due to the lack of uniformity in the $50 \%$ grafted DGN membranes: the $100 \%$ grafted membranes have the branch polymer deposits homogeneously dis- 


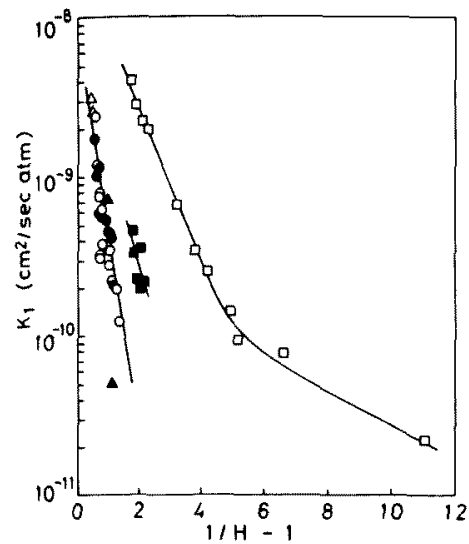

Fig. 2. Relationships between $K_{1}$ and $1 / H-1$ for DN and DGN membranes. (ㅁ) DN; DGN with $\sim 50 \%$ grafting; (A) DGN with $\sim 100 \%$ grafting; (O) DGN with $-150 \%$ grafting; (•) DGN with $-250 \%$ grafting; ( $\triangle)$ DGN with $\sim 400 \%$ grafting.

tributed. As seen in Fig. 2, the relationships between $K_{1}$ and $1 / H-1$ gave different three straight lines different from Yasuda's results. However, eq. (4) can be applied to the membranes individually except for DN membranes with low hydration. Consequently, it may be considered that $K_{0}$ and $B$ are characteristic values referring to polymer membrane properties such as fine structure of the membrane, the state of adsorbed water and the fixed charge density of the membrane. The values for $K_{0}$ and $B$ determined for those membranes are listed in Table I.

It is considered that water imbibition of polymers depends on the number of hydrophilic groups and the degree of crystallinity. Further, the hydrophilic groups of the membranes swollen in salt solutions are surrounded with pure water which corresponds to the nonfreezing water and/or the

Table I. Parameters, $K_{0}, B, k$, and $V_{1} / V_{0}$, for decrystallized nylon 6 and decrystallized grafted nylon 6 membranes.

\begin{tabular}{lrrll}
\hline \multicolumn{1}{c}{ Sample } & $K_{0} \times 10^{9}$ & \multicolumn{1}{c}{$B$} & \multicolumn{1}{c}{$k$} & $V_{1} / V_{0}$ \\
\hline DN & 26.30 & 1.12 & 3.88 & 0.18 \\
DGN 50\% & 4.61 & 1.41 & 1.0 & 0.25 \\
DGN 100\% & 7.04 & 2.85 & 0.17 & 0.35 \\
\hline
\end{tabular}

a : DGN membranes with $\sim 50 \%$ grafting.

b: DGN membranes with more than $100 \%$ grafting. bound water surrounding the hydrophilic groups. In the case of ionizable hydrophilic groups such as carboxyl groups, the water shell may also be the salt-excluding as a result of the Coulombic repulsion. The volumes per one hydrophilic group in the swollen membrane can be defined as follows; $V_{0}$ the total volume of the hydrated membrane; $V_{\mathrm{p}}$ the volume of polymer in the membrane; $V_{1}$ the volume of pure water in the membrane; and $V_{2}$ the volume of the salt solution with the same concentration of the feed. If it is assumed that volume $V_{1}$ and $V_{2}$ will allow transport of pure water and salt solution, respectively, and that the rates of the volume flows in both elements are not identical, the total water flux $J_{1}$ can be represented by the following equation:

$$
J_{1}=\Phi_{1}+\Phi_{2}
$$

where $\Phi_{1}$ and $\Phi_{2}$ are the water fluxes of the pure water and the salt solution, respectively and can be represented as follows.

$$
\begin{aligned}
& \Phi_{1}=\left(V_{1} /\left(V_{1}+k V_{2}\right)\right) J_{1} \\
& \Phi_{2}=\left(k V_{2} /\left(V_{1}+k V_{2}\right)\right) J_{1}
\end{aligned}
$$

where $k$ is the ratio of the volume flow rates of the salt solution to pure water. The salt flux $J_{2}$ and the effluent concentration $C^{\prime \prime}$ are given by

$$
J_{2}=\Phi_{2} C^{\prime} \quad \text { (8) and } C^{\prime \prime}=J_{2} / J_{1}
$$

The salt rejection $R_{\mathrm{s}}$ is given by

$$
R_{s}=1-C^{\prime \prime} / C^{\prime \prime}=1-\left(J_{2} / J_{1} C^{\prime}\right)
$$

From eqs. (7), (8), and (10), $R_{\mathrm{s}}$ can be represented by following equation:

$$
R_{s}=V_{1} /\left(V_{1}+k V_{2}\right)
$$

$R_{\mathrm{s}}$ can be also expressed in terms of the volume fraction of water $\left(H=\left(V_{1}+V_{2}\right) / V_{0}\right)$ where:

$$
1 / R_{\mathrm{s}}=\left(k V_{0} / V_{1}\right) H+(1-k)
$$

When eq. (4) is substituted in eq. (12), the following equation is obtained.

$$
1 / R_{\mathrm{s}}=\left(k V_{0} / V_{1}\right)\left(B /\left(B-\ln K_{1}+\ln K_{0}\right)\right)+(1-k)
$$

Yasuda et $\mathrm{al}^{3}$ ) assumed that the rates of volume flow in pure water and salt solution phases are identical, and they have been derived a proportional relationship between $R_{\mathrm{s}}$ and $1 / H-1$. 


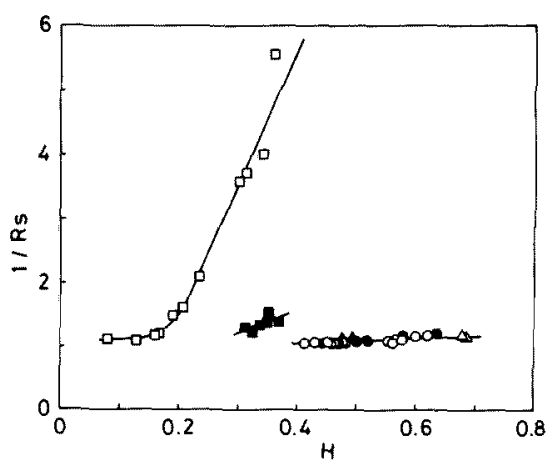

Fig. 3. Relationships between $1 / R_{\mathrm{s}}$ and $H$ for $\mathrm{DN}$ and DGN membranes. ( $\square$ ) DN; ( $)$ DGN with $\sim 50 \%$ grafting; (A) DGN with $\sim 100 \%$ grafting; (O) DGN with $\sim 150 \%$ grafting; (@) DGN with $\sim 250 \%$ grafting; $(\triangle)$ DGN with $\sim 400 \%$ grafting.

Fig. 3 shows the relationship between $1 / R_{\mathrm{s}}$ and $H$ for the membranes. Since $1 / R_{\mathrm{s}}$ increased linearly with $H$, except for DN membranes with low $H$, it is found that eq. (12) can be applied to the membranes that are highly hydrated. But there was no proportional relationship between $R_{\mathrm{s}}$ and $1 / H-1$. From eq. (12), $k$ and $V_{1} / V_{0}$ values were determined, and the results are shown in Table I. The DN membranes with higher $H^{\prime}$ values exhibit higher $k$ and lower $V_{1} / V_{0}$ values than those of DGN membranes with more than $100 \%$ grafting. The latter membranes exhibited low $k$ 's values and high $V_{1} / V_{0}$ values. DGN membranes with about $50 \%$ grafting showed medium values for both membranes. It is inferred that the pure water fraction, $V_{1} / V_{0}$, in the swollen membrane is the lowest for DN membranes, and increases with the extent of grafting. The rate of the water flux of the salt solution phase is faster than that through the pure water phase for DN membranes since the $k$ value exceeds unity. For DGN membranes with about $50 \%$ grafting, the rates show the same values in both phases. However, it is observed that the rate of the water flux is faster for the pure water phase than for the solution phase for DGN membranes with more than $100 \%$ grafting. These differences found with DN and DGN membranes may be due to the amount of carboxyl groups in the membranes and to the fine structure of the membranes resulting from graft copolymerization. The relationships between $K_{1}$ and $R_{\mathrm{s}}$ for the

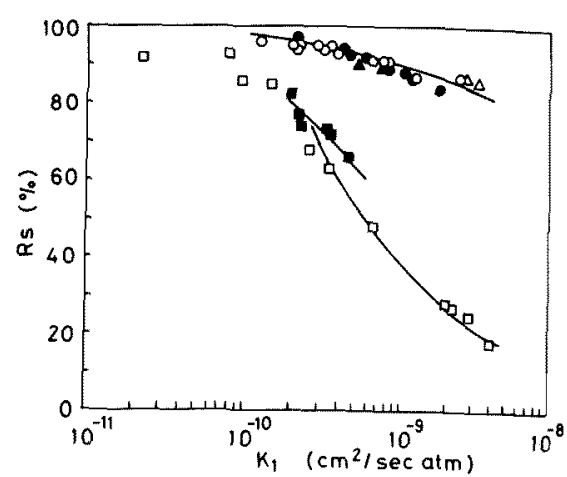

Fig. 4. Dependences of $R_{s}$ on $K_{1}$ for $\mathrm{DN}$ and DGN membranes. ( $\square$ ) DN; ( ) DGN with $\sim 50 \%$ grafting; (A) DGN with $\sim 100 \%$ grafting; (O) DGN with 150\% grafting; (•) DGN with $\sim 250 \%$ grafting; $(\triangle)$ DGN with $-400 \%$ grafting.

membranes are shown in Fig. 4. The solid lines in the figure represent values calculated from eq. (13) using the parameters listed in Table I. It is found that the calculated lines fit in with experimental points regardless of the type of membranes used. DN membranes show comparatively high $R_{\mathrm{s}}$ values in the region of low $K_{1}$. However, when $K_{1}$ exceeds $1 \times 10^{-10} \mathrm{~cm}^{2} / \mathrm{sec}$ atm, $R_{\mathrm{s}}$ decreases rapidly with increasing values of $K_{1}$. Although DGN membranes with about $50 \%$ grafting show almost the same trend as that of DN membranes, the former membranes exhibit higher $R_{\mathrm{s}}$ values than DN membranes with similar $K_{1}$ values. The values of $R_{\mathrm{s}}$ for the DGN membranes with more than $100 \%$ grafting decrease gradually with increasing $K_{1}$ values. Moreover, the DGN membranes retain higher values of $R_{\mathrm{s}}$ even at higher values of $K_{1}$ as compared with others membranes. It is considered that these behaviors of the DGN membranes are attributable to the higher value of the pure water fraction, $V_{1} / V_{0}$, and of the faster rate of the water flux through the pure water phase than that through the solution phase.

\section{References}

1) S. Takigami, M. Nakamura, and Y. Nakamura, Polymer, in press

2) S. Takigami, M. Nakamura, and Y. Nakamura, ibid.

3) H. Yasuda, C. E. Lamaze, and A. Schindler, J. Polym. Sci., A-2, 9, 1579 (1971)

4) E. Bittencourt, V. Stannett, H. B. Hopfenberg, 
and J. L. Williams, J. Appl. Polym. Sci., 26, 2897 (1981)
5) H. Yasuda, C. E. Lamaze, and A. Peterlin, J. Polym. Sci., A-2, 9, 1117 (1971)

非晶化ナイロン 6 および非晶化アクリル酸

\section{グラフトナイロン 6 膜による逆浸透}

群馬大学工学部瀧上昭治, 小林文彦, 中村好雄

ナイロン6フィルムとて線前照射法により共重合した アクリル酸グラフトナイロン 6 膜にパラホルムアルデヒ トと乳酸を蟻酸，燐酸触媒下で反心させ，得られた非晶 化ナイロン6(DN) および非晶化グラフトナイロン 6 (DGN) 膜の逆浸透举動を調へた。水の水力学的透過係 数 $\left(K_{1}\right)$ は水の体皘分率 $(H)$ の增加に伴ない増加した。 DN膜およびグラフト率 50\%のDGN膜の塩排除率 $\left(R_{\mathrm{s}}\right)$ はHの增加に伴ない減少した。一方，グラフト率 $100 \%$ 以上のDGN膜では，Hの增加に伴なう $R$, 減少は小さ く，高い $K_{1}$ 值を有する膜でも高塩排除率を保持した。
膜中の純水上塩水(原液と同じ濃度)は異なる流量速度で 膨潤膜の異なる部分を移動すると仮定し， $R_{\mathrm{B}} と K_{1} と D$ 関係を検討し， $R_{\mathrm{s}}\left\llcorner K_{1}\right.$ との間に次式を誘導した。

$$
\frac{1}{R_{\mathrm{s}}}=\left(\frac{k V_{0}}{V_{1}}\right)\left(\frac{B}{B-\ln K_{1}+\ln K_{0}}\right)+(1-k)
$$

ここで $k$ は純水相と塩水相中の体積流れの速度比， $V_{0}$ および $V_{1}$ は水膨潤膜中の親水性基 1 個当りの膨潤膜の 全体皘および純水部分の体積を，また $B$ 上 $K_{0}$ は定数を あらわす。 